\title{
Modelling a competitive field of an enterprise:
} A structural approach

\author{
Natalya Yu. Yaroshevich
}

\begin{abstract}
The article deals with modelling a competitive field of an enterprise and performs its empirical assessment. The methodological base includes the theory of industrial organization, the theory of organizational fields and the theory of competitive field. The author proves that an industrial market can be viewed as a competitive field defined by a firm (or imposed on it), where strategic interaction is realized within the framework of the status hierarchies of the participating firms. Such an approach allows looking at the market structure and behaviour of firm in more detail. To characterize a competitive field, the author uses indicators of the market structure, monopoly power and power asymmetry and substantiates the choice of the indicators for their evaluation. The modified Herfindahl-Hirschman index is applied for assessing the market structure; the Bain index is utilized to evaluate monopoly power; and its deviation is used to assess power asymmetry. Based on the combination of the selected indicators, we distinguish between four types of competitive fields and construct a matrix for determining them. The research presents the empirical testing of the proposed approach using the case study of eight industries. The findings of the empirical part unveil only three (out of four) competitive fields within the industries under study. A dynamic analysis shows that all the industries are sustainable oligopolies with a low level of competition. Competitive fields formed in the industrial markets are some sort of a trap, since they do not encourage industrial enterprises to develop technological and management innovations. The author's approach is versatile and can be used to determine a competitive field in other industrial markets.
\end{abstract}

Keywords: market structure; modelling; competitive field; enterprise; industrial market.

JEL Classification: A14, L13, L40, L10

Paper submitted: February 20, 2019.

For citation: Yaroshevich N.Yu. (2019). Modelling a competitive field of an enterprise: A structural approach. Upravlenets - The Manager, vol. 10, no. 2, pp. 31-40. DOI: 10.29141/2218-5003-2019-10-2-4.

\section{INTRODUCTION}

For any enterprise, competitiveness is one of the most important characteristics ensuring the implementation of the strategy and sustainable development of the entire industry. At the same time, the sustainability of an enterprise is determined not only by the effective use of available resources, production technologies and organizational culture, but also the capability of a firm to create a space for effective interaction.

Inter-firm cooperation in the external environment is among the topical avenues for scientific investigation. Determining the market is the main principle underlying the mechanism of this interaction. The way in which the enterprise delimits its sphere of interest, rivals and partners, rules and standards and business methods influences the depth of this concept.

The present study aims to perform a theoretical modelling and empirical assessment of the functioning of an enterprise's competitive field. To achieve the stated goal, the following tasks have to be fulfilled:

1) to systematize the approaches to the definition of the concept of industrial market and a market as a competitive field, in particular;

2) to conduct modelling and create a typology of an enterprise's competitive field;

3) to carry out an empirical analysis of the special features of a competitive field's functioning using the case of manufacturing industries.

In the current research, we focus on the mechanisms of interaction between industrial enterprises within their industrial markets. The object of the study is eight industries of the real sector of economy.
Manufacturing has always been the backbone of the Russian economy. Its development stimulates most other economic sectors to grow. The competitive business models practiced by industrial enterprises are rather diverse. The choice of a particular business model is largely dependent on external factors of the industrial market's structure.

\section{INDUSTRIAL MARKET AS A COMPETITIVE FIELD: \\ CLARIFICATION OF THE CONCEPT}

To define industrial market as a competitive field, it is necessary to combine three concepts: the theory of industrial organization, the theory of organizational fields and the theory of competitive field.

Within the framework of the theory of industrial organization, the problem with defining a market is associated with the definition of the term "industry".

According to Mason [1939], the term "market" implies the Marshallian industry, i.e. a census industry that approximately satisfies product and spatial requirements. The winning argument was put forward by the English economist Andrews, who stated that "governments tend to do business using the terms of industries, businessmen in their considerations proceed from industry conditions, and our official statistics continue to collect data based on industry definitions, which, if vary from source to source, are still coherent" [Kamensky, 1909].

Tirole [2000, p. 28] proposed the following definition of the term "market": market is well defined, and that it involves either a homogeneous good or a group of differentiated products that are fairly good substitutes (or complements) for at least one good in the group and have limited interaction with the rest of the economy. 
In Abell's perspective [1990], a market is defined in three dimensions:

1) what are the needs, functions or combinations of functions that have to be met? (what?);

2) what are the different consumer groups that you need to satisfy? (for whom?);

3) what are the existing technologies to perform these functions (how?).

According to the Russian scholars, market implies economic relationships built upon market laws and principles [Raizberg, 2000, p. 241]. Generalizing the concept of market means combining all elements of the market system in it. At that, the higher the level of competition in the industrial markets, the more identical the terms "industry" and "market" for certain goods and services.

When defining the market within the framework of industry theory, it is possible to combine the market and industry.

Thus, market is a set of enterprises producing goods similar in terms of their customer orientation while using much the same technologies and production resources and competing with each other for selling their products on the market.

The industrial approach allows classifying market according to the level of competition through analyzing the level of concentration and monopoly power, the severity of entry barriers and the degree of product differentiation. However, this approach does not fully disclose the dynamics of an industry market's development and the distinguishing features of competitive interaction in this market.

A market today is not a static object, but it is considered "in the state of formation and transformation, when the relationships of its participants are increasingly mobile" [Radaev, 2010, p. 5].

Dealing with market from the standpoint of the theory of organizational fields is based on the structuring and institutionalization of interaction mechanisms in the industry market. The concept of field is regarded in two possible interpretations: structural and interactionist [Gavetti, 2012, p. 267; Zhang, Gao, 2014, p. 247].

The ideologist of the structural approach is P. Bourdieu, who stated that market was a part of the social space and a result of the mutual positioning of enterprises belonging to the same sector or industry, but differing in the volume and structure of their capital [Bourdieu, 2005, p. 147].

At the same time, capital refers to economic capital, which is also heterogeneous and includes financial, technological, organizational and trading capital. Within the structural concept of the field, the distribution of capital forms its structure, which, in turn, determines the barriers to entry and the opportunities for economically profitable activity.

According to Bourdieu [2005, p. 149], the main factor is the market share of an enterprise; the competitive interaction happening in the market is determined precisely by the structure of the field and the market power of individual firms. He states that the dominating position in the structure makes it possible for the leading firms to establish the order and the rules of the game and its limits. By the very fact of their existence, which is equal in strength to their actions, market leaders can change the entire environment of other companies and the system of current restrictions.

The interactionist approach of the organizational field theory developed by Neil Fligstein is premised on the interaction of firms as the main structural factor. Fligstein [2002] argues that fields are institutionalized interaction arenas where actors with different organizational capabilities build their behavior towards each other.

Combining these two approaches, we can conclude that in both cases, market participants are differentiated, and the process of their interaction reproduces relatively stable status hierarchies within the framework of the industry market.

Thus, the main characteristics of the industry market within the framework of the theory of organizational fields are indicators characterizing the structure, monopoly power and stability of the current power hierarchy.

The theory of the competitive field is a logical complement to the approach to defining the market within the framework of the theory of organizational fields.

Within the confines of the theory of the competitive field, there are a multitude of synonyms of this term, e.g. a playing field of competitors [Adikesavan, 2014, p. 372], a firm's competitive space [Porter, 2005, p. 113], competitive arena [Liu, Li, 2005, p. 64], competitive market map [Hughes, 1999, p. 822].

Rubin $[2014$, p. 124] offers the most complete description of a competitive field. This is the means of competitors' interaction used in a particular market. Rubin compares a competitive field with a football one: "Football teams compete either on the home field (a stadium owned by one of the clubs or located at its base site), or on a foreign turf (an opponent's stadium)".

On the home field, a firm sets out its own rules and the game strategy, and on the foreign turf, it chooses competitive tools that ensure confrontation to be productive. Choosing the "right" competitive field will produce better economic results for a firm in comparison with its rivals.

The concept of a competitive space of a firm framed by Karpov is a synonym of the competitive field. A competitive space of a firm refers to a variety of choices that are available and effective for a firm [Karpov, 2008, p. 252]. The number and composition of participants of the competitive field are determined by the level of their monopoly power. Using the traditional microeconomic approach, a competitive field can be depicted as a diagram whose upper limit is the demand curve and the lower limit is the average cost curve. The area of such a diagram displays the variety of available and effective choices of "price-output" for the company in the prevailing industry market conditions.

The stronger the firm's monopoly power in the market, the less its competitive field and the greater the opportunity to shape the strategic behavior of competitors.

Thus, a competitive field is a part of the market delimited by the firm (or imposed on it in accordance with its market position), where it is able to fully realize its monopoly power and competitive advantages. Monopoly power and power 
asymmetry are the central parameters for evaluating a competitive field of a firm. Table 1 presents the integration of these three approaches.

If combine all the three approaches, an industry market can be viewed as a competitive field determined by the firm (or imposed on it), where strategic interaction is realized within the framework of member firms' status hierarchies.

\section{TOOLS FOR ANALYZING THE STRUCTURE}

\section{ENTERPRISE'S OF AN COMPETITIVE FIELD}

A competitive field is the external environment, in which an enterprise operates. On the one hand, the field's structure is predetermined by the behavior of its participants. On the other hand, it is formed under the influence of their behavior.

Manufacturing industries manage to combine classical patterns and specificity of the development.

When interpreting a market as a competitive field, a number of indicators need to be identified. These are indicators of the market structure, monopoly power and power asymmetry.

Heterogeneity of market participants' position, i.e. the concentration level, is one of the most important indicators of the structure. It reflects not only the degree of concentration or monopoly power within the field where industrial enterprises operate, but the field's size as well. For instance, it allows identifying market leaders, their number and market share. Nowadays, researchers [Sherer, Ross, 1991, p. 58] use a variety of concentration indicators: the concentration ratio, the Herfindahl-Hirschman index, the Hall-Tideman index, market share dispersion, etc. Within the scope of the current study, it is expedient to use the Herfindahl-Hirschman index and the concentration ratio. The former makes it possible to determine the level of the environment's heterogeneity, and the latter establishes the presence of leaders, their share and the size of the competitive field.

The Herfindahl-Hirschman index is calculated using the following formula:

$$
H H I=\sum_{i=1}^{n} q_{i}^{2},
$$

where $q_{i}$ is a firm's market share; $n$ is the number of firms functioning the industry under consideration.
The heterogeneity of the industry market's environment can be evaluated using the modified Herfindahl-Hirschman index:

$$
H H I=n \sigma^{2}+\frac{1}{n},
$$

where $\sigma^{2}$ is market share dispersion.

The concentration ratio is calculated by formula:

$$
C R_{n}=\sum_{i=1}^{n} q_{i}
$$

where $n$ is the number of market leaders in the industry.

To evaluate market shares, it is possible to use various indicators of enterprises performance, such as sales volume, profit, etc.

To assess a competitive field, we should set the values of these coefficients.

In order to assess the presence of a competitive field in the industry market, the Herfindahl-Hirschman index is necessary to be calculated.

If its value varies from 1000 to 1800 , the concentration level is average and a competitive field is wide; if the value is over 1800 , this indicates a high level of concentration and a narrow competitive field. The values of the concentration ratio will complement this assessment. The concentration ratio is calculated for the leading companies; there may be three, five, eight, twelve of them. Hence, the indicator's value will characterize the size of the competitive field. The higher the concentration ratio, the narrower the competitive field in the industry under review.

The next step in analyzing a competitive field is to evaluate the level of monopoly power of the companies operating there. The Bain index is one of the most widespread indicators used to determine monopoly power [Sherer, Ross, 1991, p. 60]. It shows a firm's economic profit per one ruble of its own invested capital:

$$
B=\frac{P_{A}-P_{N}}{F_{C}},
$$

where $P_{A}$ is accounting profit; $P_{N}$ is normal profit; $F_{C}$ is a firm's own capital. If the Bain index is greater than one, it means that the competition in the market is tough and firms actively use strategic and marketing tools to maintain monopoly power and high investment attractiveness.

Table 1 - Approaches to the definition of market Таблица 1 - Подходы к определению рынка

\begin{tabular}{|l|l|l|l|}
\hline \multicolumn{1}{|c|}{ Characteristic } & \multicolumn{1}{|c|}{ Theory of industrial organization } & \multicolumn{1}{|c|}{ Theory of inter-organizational fields } & \multicolumn{1}{c|}{ Theory of competitive field } \\
\hline Market & $\begin{array}{l}\text { A set of enterprises producing goods } \\
\text { similar in terms of their customer ori- } \\
\text { entation while using much the same } \\
\text { technologies and production resourc- } \\
\text { es and competing with each other for } \\
\text { selling their products on the market }\end{array}$ & $\begin{array}{l}\text { Institutionalized interaction arenas } \\
\text { where actors with various organiza- } \\
\text { tional capabilities build their behavior } \\
\text { towards each other }\end{array}$ & $\begin{array}{l}\text { Part of } \\
\text { firm } \text { the } \text { imposed on it in accordance } \\
\text { with market position), where it is } \\
\text { able to fully realize its monopoly power } \\
\text { and competitive advantages }\end{array}$ \\
\hline $\begin{array}{l}\text { Object } \\
\text { of the evaluation }\end{array}$ & The number and scale of firms & Interaction between firms & $\begin{array}{l}\text { Interaction between firms, hierarchi- } \\
\text { cal interaction }\end{array}$ \\
\hline $\begin{array}{l}\text { Evaluation pa- } \\
\text { rameters }\end{array}$ & Market structure & The size of firms, monopoly power & Monopoly power, power asymmetry \\
\hline
\end{tabular}


It is also expedient to assess not only the Bain index for market leaders, but also the variation of its values using the deviation formula:

$$
\sigma_{I_{B}}=\frac{\sum_{i=1}^{n}\left(I_{B i}-\overline{I_{B}}\right)}{n},
$$

where $I_{B i}$ is the Bain index for a particular firm; $\overline{I_{B}}$ is the average Bain index calculated for a given competitive field; $n$ is the number of firms in a competitive field.

The high value of the index among market leaders signifies that there is power asymmetry within the competitive field, which makes it possible to identify the companies forming the competitive field and those adapting to it. In the future, this will clearly define the boundaries of the competitive field of a specific industry market.

Thus, depending on the combination of the above-mentioned indicators, we can distinguish between eight types of competitive fields that differ in the size, competitive intensity and the dominance of leaders. Figure 1 demonstrates the classification scheme proposed and used by the author to evaluate competitive fields.

Table 2 presents eight types of competitive fields. The classification uses qualitative characteristics of selected indicators. If the Herfindahl-Hirschman index is greater than 1000 , it shows that there is a competitive field in the market.

Table 2 - Types of competitive fields Таблица 2 - Типы конкурентного поля

\begin{tabular}{|l|c|c|c|c|c|c|}
\hline \multirow{2}{*}{\begin{tabular}{c}
\multirow{2}{*}{$\begin{array}{c}\text { Types } \\
\text { of competitive } \\
\text { fields }\end{array}$} \\
\cline { 2 - 8 }
\end{tabular}} & \multicolumn{2}{c|}{$C R_{n}$} & \multicolumn{2}{c|}{$I_{B}$} & \multicolumn{2}{c|}{$\sigma_{I_{B}}$} \\
\cline { 2 - 8 } & High & Low & High & Low & High & Low \\
\hline Fecond & + & - & + & - & + & - \\
\hline Third & + & - & + & - & - & + \\
\hline Fourth & + & - & - & + & + & - \\
\hline Fifth & + & - & - & + & - & + \\
\hline Sixth & - & + & + & - & + & - \\
\hline Seventh & - & + & + & - & - & + \\
\hline Eighth & - & + & - & + & + & - \\
\hline
\end{tabular}

Note. The "+" symbol means the presence of the sign; the "-" symbol means its absence.

The value of the concentration ratio, calculated for eight largest firms in the industry, will determine its size. If the ratio is above $50 \%$, a competitive field in the industry market is narrow with obvious dominant firms.
With the Bain index greater than one, the market is characterized by an intense competition, which implies the active use of marketing and strategic tools. Complementing the calculation with an indicator of the standard deviation of the Bain index, with the value greater than one, we can state that there is a clear leader forming a competitive field.

Let us briefly describe the distinctive features of the identified types of competitive fields.

All the market under consideration are oligopolies. The analysis carried out according to the presented indicators makes it possible to determine oligopolies, which represent the objective state of the market, i.e. associated with the technological specificity of production and the geographical spread of the markets, and oligopolies formed by the competitive behavior of firms in the given industry market.

The first four types will be characterized by a high value of the concentration ratio and, accordingly, a narrow competitive field. High values of the Bain index (the first and second types) show the presence of competition between firms. At that, the high value of the Bain index deviation (the first type) indicates the presence of a dominant firm and the competitive field it forms. The second type is described by a low value of the indicator and can point to the equilibrium state in the competitive field, which can be explained by the presence of a tacit collusion.

The low value of the Bain index (the third and fourth type) exhibits the absence of competition, which is most likely due to the technological peculiarities of industrial production (for example, narrow specialization). The same is typical of the seventh and the eighth types. Hence, such types cannot be regarded as a competitive field.

As for the fifth and the sixth types, low values of the concentration ratio will correspond to a wide competitive field, and high values of the Bain index and its standard deviation will indicate the presence of severe competition and the dominant leader forming the field.

This allows us to design a matrix for defining a competitive field (Fig. 2).

The proposed classification is rather conditional and does not allow one to fully describe the diversity of the competitive interaction between companies in industry markets. However, this approach is useful, since it allows firms to determine their relevant business strategies and specific behavior models.

Consider this approach when assessing the specificity of industry markets of the Russian economy.

Selected classification characteristics of a competitive field

Fig. 1. Classification of competitive fields

Рис. 1. Классификация конкурентного поля 


\begin{tabular}{|c|c|c|c|}
\hline & \multicolumn{2}{|c|}{ Size of a competitive field } \\
\hline & & Narrow & Wide \\
\hline \multirow{2}{*}{ 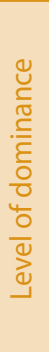 } & $\begin{array}{l}\text { 일 } \\
\text { 호 }\end{array}$ & $\begin{array}{c}\text { The number of firms - from } 3 \text { to } 5 ; \\
\text { one obvious dominant leader; } \\
\text { condition to gain the competitive advantage - } \\
\text { a corporate strategy and innovation development; } \\
\text { long-term leadership }\end{array}$ & $\begin{array}{l}\text { The number of firms - } 5 \text { or more; } \\
\text { several obvious dominant leaders (from } 1 \text { to } 3 \text { ); } \\
\text { condition to gain the competitive advantage - } \\
\text { corporate strategies and innovation development; } \\
\text { short-term leadership }\end{array}$ \\
\hline & 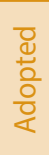 & $\begin{array}{c}\text { The number of firms - less than } 5 \text {; } \\
\text { dominance of participants is due to technological } \\
\text { or institutional particularities of the industry; } \\
\text { a time-stable field }\end{array}$ & $\begin{array}{l}\text { The number of firms }-5 \text { or more; } \\
\text { coordination behavior mechanisms in the market; } \\
\text { impaired market coordination }\end{array}$ \\
\hline
\end{tabular}

Fig. 2. Matrix for defining a competitive field

\section{Рис. 2. Матрица определения конкурентного поля}

\section{CONSTRUCTING AN INDUSTRIAL ENTERPRISE'S COMPETITIVE FIELD}

For the purposes of the given study, we concentrate on eight industries with the $H H I$ value more than 1000 . The sample includes the industries related to the real sector of economy which are analysed within the country boundaries. The data were retrieved from SPARK-Interfax database.

Table 3 shows the data on the selected industries. All the selected industries are oligopolies. Most industries demonstrate the average $\mathrm{HHI}$ value; the only industry with the high value of the index is manufacturing products using powder metallurgy. At the same time, none of the industries exhibits the Bain index value greater than 1, which means that, despite high values of the concentration ratio, its intensity in in- dustries is low. The actual limits of a competitive field should be assessed by analyzing the concentration ratio in dynamics, for each industry individually.

\section{Industry 24.10. Iron, steel and ferroalloys production}

We calculate the concentration ratio for three, eight and twelve largest firms in the industry, as well as the Bain index and its deviation in dynamics for 16 years - from 2000 to 2016 (Table 4).

The values of the concentration ratios show that a competitive field is limited at the level of three largest companies of the industry, which determine the intensity of competition. At that, the change in the values of the Bain index and its deviation is insignificant but positive, which indicates a trend towards a growing competition in the market.

Table 3 - Descriptive characteristics of the industry sample Таблица 3 - Описательные характеристики отраслевой выборки

\begin{tabular}{|c|c|c|c|c|c|c|c|c|}
\hline \multirow{2}{*}{ No. } & \multirow{2}{*}{$\begin{array}{l}\text { OKVED }^{1} \\
\text { code }\end{array}$} & \multirow{2}{*}{ Industry } & \multirow{2}{*}{ Main activities } & \multirow{2}{*}{$\begin{array}{l}\text { Number } \\
\text { of companies } \\
\text { in the industry }\end{array}$} & \multicolumn{4}{|c|}{ Number of companies in the industry } \\
\hline & & & & & $H H I$ & $C R_{8}$ & $I_{B}$ & $\sigma_{I_{B}}$ \\
\hline 1 & 24.10 & $\begin{array}{l}\text { Iron, steel and ferroalloys } \\
\text { production }\end{array}$ & $\begin{array}{l}\text { Production of foundry and mirror } \\
\text { cast iron in ingots, blocks or other } \\
\text { primary forms, ferroalloys, steel } \\
\text { products, etc. }\end{array}$ & 815 & 1095 & 77.3 & 0.37 & 0.48 \\
\hline 2 & 25.50 .2 & $\begin{array}{l}\text { Manufacturing products using } \\
\text { powder metallurgy }\end{array}$ & $\begin{array}{l}\text { Manufacturing products using } \\
\text { powder metallurgy }\end{array}$ & 59 & 3802 & 90.4 & 0.27 & 0.183 \\
\hline 3 & 30.11 & $\begin{array}{l}\text { Construction of ships, vessels } \\
\text { and floating structures }\end{array}$ & $\begin{array}{l}\text { Construction of ships and } \\
\text { vessels: passenger, cargo, } \\
\text { tankers, icebreakers, gas carriers, } \\
\text { reefer ships, tugboats, pushers, } \\
\text { etc. }\end{array}$ & 1161 & 1436 & 80.0 & 0.04 & 0.182 \\
\hline 4 & 22.19.3 & $\begin{array}{l}\text { Manufacture of other rubber } \\
\text { products }\end{array}$ & $\begin{array}{l}\text { Manufacturing rubber materials } \\
\text { for repair }\end{array}$ & 230 & 1440 & 72.0 & 0.356 & 0.314 \\
\hline 5 & 28.13 & $\begin{array}{l}\text { Manufacture of other pumps } \\
\text { and compressors }\end{array}$ & $\begin{array}{l}\text { Manufacture of air or vacuum } \\
\text { pumps, air or other gas } \\
\text { compressors, etc. }\end{array}$ & 276 & 1056 & 63.5 & 0.08 & 0.04 \\
\hline 6 & 29.10 .2 & Car production & Car production & 50 & 1608 & 91.9 & 0.209 & 0.14 \\
\hline 7 & 28.3 & $\begin{array}{l}\text { Manufacture of machinery } \\
\text { and equipment for agriculture } \\
\text { and forestry }\end{array}$ & $\begin{array}{l}\text { Manufacture of machinery and } \\
\text { equipment for agriculture and } \\
\text { forestry }\end{array}$ & 786 & 1060.82 & 63.50 & 0.6 & 1.03 \\
\hline 8 & 24.2 & $\begin{array}{l}\text { Manufacture of steel pipes, } \\
\text { hollow profiles and fittings }\end{array}$ & $\begin{array}{l}\text { Manufacture of steel pipes, } \\
\text { hollow profiles and fittings }\end{array}$ & 424 & 1003.2 & 68.4 & 0.136 & 0.152 \\
\hline
\end{tabular}

${ }^{1}$ OKVED - Russian National Classifier of Types of Economic Activity. 
Table 4 - Values of the concentration ratio, the Bain index and its deviation for the Industry 24.10 for 2000-2016

Таблица 4 - Значения коэффициента концентрации, коэффициента Бейна и его отклонения для отрасли 24.10 за 2000-2016 гг.

\begin{tabular}{|l|c|c|c|c|c|}
\hline Indicator & 2000 & 2005 & 2010 & 2015 & 2016 \\
\hline$C R_{3}$ & 64.9 & 57.4 & 51.3 & 53.6 & 53.0 \\
\hline$C R_{8}$ & 88.5 & 84.4 & 79.5 & 78.3 & 77.3 \\
\hline$C R_{12}$ & 93.3 & 89.7 & 86.0 & 84.1 & 84.1 \\
\hline$I_{B}$ & 0.417 & 0.490 & 0.185 & 0.211 & 0.378 \\
\hline$\sigma_{I_{B}}$ & 0.17 & 0.18 & 0.08 & 0.15 & 0.48 \\
\hline
\end{tabular}

Thus, the industry of iron, steel and ferroalloys production can be classified as the third type of competitive field.

\section{Industry 25.50.2. Manufacturing products using powder metallurgy}

Table 5 presents the dynamics of the concentration ratio for three, eight and twelve largest firms on the industry under study, as well as the Bain index and its deviation for 16 years - from 2000 to 2016.

Table 5 - Values of the concentration ratio, the Bain index and its deviation for the Industry 25.50.2 for 2000-2016

Таблица 5 - Значения коэффициента концентрации, коэффициента Бейна и его отклонения для отрасли 25.50.2 за 2000-2016 гг.

\begin{tabular}{|l|c|c|c|c|c|}
\hline Indicator & 2000 & 2005 & 2010 & 2015 & 2016 \\
\hline$C R_{3}$ & 90.0 & 85.3 & 78.4 & 68.1 & 79.0 \\
\hline$C R_{8}$ & 96.9 & 98 & 94,2 & 85.7 & 90.4 \\
\hline$C R_{12}$ & 96.9 & 98 & 96.8 & 91,6 & 94.6 \\
\hline$I_{B}$ & 0.41 & 0.252 & 0.073 & 0.28 & 0.27 \\
\hline$\sigma_{I_{B}}$ & 0.89 & 0.275 & 0.05 & 0.199 & 0.183 \\
\hline
\end{tabular}

A dynamic analysis of the concentration ratios calculated for three, eight and twelve companies in the industry displays a high level of competition at the level of three companies; the values of the Bain index and its deviation are very low.

Thus, for the market for products manufactured using powder metallurgy, the formation of a competitive field also occurs at the level of three leading companies, but the intensity of competition is low. The competitive field of this industry market belongs to the third type.

\section{Industry 30.11. Construction of ships, vessels and floating structures}

Let us analyze the dynamics of changes in the concentration ratio and the Bain index for the industry of ships, vessels and floating structures construction (Table 6).

The analysis allows determining the boundaries of the competitive field at the level of the first three companies. Low values of the Bain index and its deviation indicate the absence of competitive behavior in the industry market. Therefore, the competitive field of the industry of ships, vessels and floating structures construction can also be included in the third type.
Table 6 - Values of the concentration ratio, the Bain index and its deviation for the Industry 30.11 for 2000-2016

Таблица 6 - Значения коэффициента концентрации, коэффициента Бейна и его отклонения для отрасли 30.11 за 2000-2016 гг.

\begin{tabular}{|l|c|c|c|c|c|}
\hline Indicator & 2000 & 2005 & 2010 & 2015 & 2016 \\
\hline$C R_{3}$ & 77.5 & 73.2 & 55.8 & 50.1 & 62.20 \\
\hline$C R_{8}$ & 88.2 & 84.7 & 83.0 & 76.8 & 80.0 \\
\hline$C R_{12}$ & 88.2 & 86.7 & 89.7 & 86.2 & 86.8 \\
\hline$I_{B}$ & 0.2 & 0.103 & 0.65 & 0.023 & 0.4 \\
\hline$\sigma_{I_{B}}$ & 0.176 & 0.368 & 0.87 & 0.04 & 0.182 \\
\hline
\end{tabular}

Industry 22.19.3.

\section{Manufacture of other rubber products}

Table 7 provides the dynamics of the concentration ratio, the Bain index and its deviation for the period of 2000-2016.

Table 7 - Values of the concentration ratio, the Bain index and its deviation for the Industry 22.19.3 for 2000-2016

Таблица 7 - Значения коэффициента концентрации, коэффициента Бейна и его отклонения для отрасли 22.19.3 за период с 2000-2016 гг.

\begin{tabular}{|l|c|c|c|c|c|}
\hline Indicator & 2000 & 2005 & 2010 & 2015 & 2016 \\
\hline$C R_{3}$ & 94.2 & 93.4 & 75.3 & 60.1 & 56.0 \\
\hline$C R_{8}$ & 94.25 & 97.2 & 86.8 & 73.8 & 72.0 \\
\hline$C R_{12}$ & 94.25 & 97.2 & 93.0 & 79.7 & 80.0 \\
\hline$I_{B}$ & 0.26 & 0.22 & 0.252 & 0.361 & 0.356 \\
\hline$\sigma_{I_{B}}$ & 0.23 & 0.4 & 0.25 & 0.425 & 0.314 \\
\hline
\end{tabular}

Over the period under review, the concentration ratios calculated for the three largest companies in the industry decreased by $38 \%$; the competitive field's boundaries did not widen staying at the level of the first three companies. Low values of the Bain index and its deviation indicate the lack of competition in the industry. The given market belongs to the third type of a competitive field.

\section{Industry 28.13.}

\section{Manufacture of other pumps and compressors}

Let us perform a dynamic analysis of the market for pumps and compressors and determine the limits of its competitive field (Table 8).

Table 8 - Values of the concentration ratio, the Bain index and its deviation for the Industry 28.13 for 2000-2016

Таблица 8 - Значения коэффициента концентрации, коэффициента Бейна и его отклонения для отрасли 28.13 за 2000-2016 гг.

\begin{tabular}{|l|c|c|c|c|c|}
\hline Indicator & 2000 & 2005 & 2010 & 2015 & 2016 \\
\hline$C R_{3}$ & 57.0 & 48.0 & 44.7 & 43.5 & 42.9 \\
\hline$C R_{8}$ & 74.7 & 71.7 & 71.7 & 66.4 & 63.5 \\
\hline$C R_{12}$ & 81.1 & 80.5 & 81.7 & 79.3 & 70.8 \\
\hline$I_{B}$ & 0.47 & 0.131 & 0.17 & 0.062 & 0.08 \\
\hline$\sigma_{I_{B}}$ & 0.35 & 0.06 & 0.03 & 0.05 & 0.04 \\
\hline
\end{tabular}


The dynamic analysis of the concentration ratios for three, eight and twelve largest companies in the industry leads to the following conclusions: the level of concentration in the industry is gradually decreasing; the borders of the competitive field match the level of the first eight companies.

Low values of the Bain index and its deviation indicate the absence of competition in the market. Accordingly, the existing structure of market leadership stems from the institutional and technical peculiarities of the industry. The competitive field of the industry belongs to the third type.

\section{Industry 29.10.2. Car production}

Look at the dynamics of the concentration ratio for three, eight and twelve largest firms in the analyzed industry, as well as the Bain index and its deviation for 16 years - from 2000 to 2016 (Table 9).

Table 9 - Values of the concentration ratio, the Bain index and its deviation for the Industry 29.10.2 for 2000-2016

Таблица 9 - Значения коэффициента концентрации, коэффициента Бейна и его отклонения для отрасли 29.10.2 за 2000-2016 гг

\begin{tabular}{|l|c|c|c|c|c|}
\hline Indicator & 2000 & 2005 & 2010 & 2015 & 2016 \\
\hline $\mathrm{CR}_{3}$ & 71.4 & 70.1 & 68.1 & 61.4 & 62.0 \\
\hline$C R_{8}$ & 93.0 & 92.0 & 92.7 & 87.6 & 91.0 \\
\hline$C R_{12}$ & 98.8 & 98.4 & 98.7 & 98.0 & 98.3 \\
\hline$I_{B}$ & 0.32 & 0.24 & 0.19 & 0.36 & 0.209 \\
\hline$\sigma_{I_{B}}$ & 0.18 & 0.13 & 0.253 & 0.65 & 0.14 \\
\hline
\end{tabular}

The values of the concentration ratios and their dynamics prove that a competitive field is time-stable and its boundaries match the level of three largest companies. At that, low values of the Bain index and its deviation indicate the absence of competitive behavior among the leading companies. Such a competitive field is narrow and adopted and can be included in the third type.

\section{Industry 28.3. Manufacture of machinery and equipment for agriculture and forestry}

Similarly, we analyze the dynamics of the concentration ratio calculated for three, eight and twelve largest companies in the industry; the Bain index and its deviation for the period from 2000 to 2016 (Table 10).

Table 10 - Values of the concentration ratio, the Bain index and its deviation for the Industry 28.3 for 2000-2016

Таблица 10 - Значения коэффициента концентрации, коэффициента Бейна и его отклонения для отрасли 28.3 за 2000-2016 гг.

\begin{tabular}{|l|c|c|c|c|c|}
\hline Indicator & 2000 & 2005 & 2010 & 2015 & 2016 \\
\hline$C R_{3}$ & 50.2 & 48.8 & 46.4 & 42.2 & 43.3 \\
\hline$C R_{8}$ & 68.8 & 67.4 & 65.4 & 62.1 & 63.5 \\
\hline$C R_{12}$ & 75.2 & 72.6 & 70.8 & 70.2 & 70.0 \\
\hline$I_{B}$ & 0.82 & 0.58 & 0.68 & 0.7 & 0.6 \\
\hline$\sigma_{I_{B}}$ & 0.68 & 0.73 & 0.8 & 1.01 & 1.03 \\
\hline
\end{tabular}




\begin{tabular}{|c|c|c|c|}
\hline & & \multicolumn{2}{|c|}{ Size of a competitive field } \\
\hline & & Narrow & Wide \\
\hline \multirow{2}{*}{ 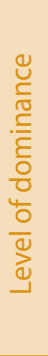 } & $\begin{array}{l}\text { 미 } \\
\text { है } \\
\text { 노 }\end{array}$ & - & $\begin{array}{l}\text { 28.3. Manufacture of machinery and equipment for agricul- } \\
\text { ture and forestry }\end{array}$ \\
\hline & $\begin{array}{l}\text { 밈 } \\
\frac{0}{0} \\
\frac{0}{0}\end{array}$ & $\begin{array}{l}\text { 29.10.2. Car production. } \\
\text { 28.13. Manufacture of other pumps and compressors. } \\
\text { 30.11. Construction of ships, vessels and floating structures. } \\
\text { 25.50.2. Manufacturing products using powder metallurgy. } \\
\text { 24.10. Iron, steel and ferroalloys production. } \\
\text { 22.19.3. Manufacture of other rubber products }\end{array}$ & 24.2. Manufacture of steel pipes, hollow profiles and fittings \\
\hline
\end{tabular}

Fig. 3. The matrix of Russian industries' competitive fields

Рис. 3. Матрица конкурентных полей отраслей промышленности России

\section{CONCLUSION}

A firm's behavior is much dependent on the peculiarities of the industry market where it operates. The market structure is predetermined by a multitude of factors and the standard approaches cannot always describe it fully and accurately. The approach developed by the author makes it possible to characterize it through not only structural, but also behavioral assessments. The dynamic analysis of the concentration ratio, the Bain index and its deviation allowed revealing four types of competitive fields in oligopolistic markets.

The empirical analysis of eight Russian industries showed that all the selected industries are sustainable oligopolies. High levels of concentration, their stable values in dynamics prove that the existing market structures are fully formed.
Low values of the Bain index and its deviation in most cases confirm that competition in the markets is weak.

Considering the trends observed in the studied markets, significant shifts in the development of the analyzed industries are hardly expected. The competitive fields formed in the industry markets are a kind of "trap" because they do not encourage companies to use technological and managerial innovations and develop competitive behavior.

The research can be developed further through expanding the boundaries of the markets under consideration. The given research can be of special interest for industrialists and government structures when developing strategies and government industry policy.

\section{References}

Bourdieu P. (2005). Pole ekonomiki [The field of economy]. In: Bourdieu P. Sotsial'noe prostranstvo: polya i praktiki [Social space: fields and practices]. Ed. by N.A. Shmatko. Moscow: Aleteyya. Pp. 129-176.

Kamenskiy P.V. (1909). Znachenie torgovo-promyshlennykh trestov na Zapade i u nas [The role of commercial and industrial trusts in the West and in our country]. Moscow.

Karpov A.L. (2008). Model' konkurentnogo povedeniya i konkurentnoe prostranstvo firmy [Model of competitive behavior and competitive space of a company]. Ekonomika regiona. Prilozhenie k № 4 - Economy of Region. Supplement to No. 4 , pp. 248-255.

Rayzberg B.A. (ed.). (2000). Kurs ekonomiki [The course of economics]. Moscow: INFRA-M.

Porter M. (2005). Competitive Strategy: Techniques for Analyzing Industries and Competitors (Russ. ed.: Porter M. Konkurentnaya strategiya. Metodika otrasley i konkurentov. Moscow: Al'pina Biznes Buks. Pp. 111-113).

Radaev V. (2010). Kak organizuetsya rynochnoe vzaimodeystvie: preprint WP4/2010/01 [How market interaction is organized. Preprint WP4/2010/01]. Moscow: GU-VShE.

Rubin Yu.B. Strategii konkurentnykh deystviy [Strategies for competitive action]. Sovremennaya konkurentsiya - Modern Competition, 2014, vol. 4(46), pp. 101-143.

Tirole J. (2000). Rynki i rynochnaya vlast': teoriya organizatsii promyshlennosti [Markets and market power: the theory of industrial organization]. Ed. by V.M. Gal'perin, I.A. Zenkevich. St. Petersburg: Ekonomicheskaya shkola. Vol. 1.

Fligstein N. (2002). Polya, vlast' i sotsial'nye navyki: kriticheskiy analiz novykh institutsional'nykh techeniy [Fields, Power and Social Skill: A Critical Analysis of the New Institutionalism]. In: Radaev V.V. (ed.). Ekonomicheskaya sotsiologiya: novye podkhody k institutsional'nomu i setevomu analizu [Economic sociology: new approaches to institutional and network analysis]. Moscow: ROSSPEN. Pp.119-156.

Abell D.E. (1980). Defining the Business: The Starting Point of Strategies Planning. Prentice-Hall, Englewood Cliffs.

Adikesavan T.A. (2014). Management information systems: best practices and applications in business. PHI Learning Private Limited.

Gavetti G. (2012). Toward a Behavioral Theory of Strategy. Organization Science, vol. 23, no. 1 (January-February), pp. 267-285.

Hughes A. (1999). Constructing Competitive Spaces: On the Corporate Practice of British Retailer-Supplier Relationships. Environment and Planning A: Economy and Space, vol. 31, no. 5 (May), pp. 819-839. 
Liu Y., Li T. (2005). The Research of Enterprise Competition Behavior and the Theory of Dynamic Competition Environment. Journal of Information, no. 7, pp. 64-66.

Mason E.S. (1939). Price and Production Policies of Large Scale Enterprise. The American Economic Review, no. 29, pp. 61-74.

Scherer F.M., Ross D. (1990). Industrial market structure and economic performance. 3rd ed. Boston: Houghton Miffin Co.

Zhang J.B., Gao D. (2014). Review on the Research of Dynamic Competition Theory. Journal of Human Resource and Sustainability Studies, no. 2, pp. 246-251.

\section{Information about the author}

\section{Natalya Yu. YAROSHEVICH}

Cand. Sc. (Econ.), Associate Professor of Enterprises Economics Dept. Ural State University of Economics (62/45 8 Marta/Narodnoy Voli St., Ekaterinburg, 620144, Russia). E-mail: iarnat@mail.ru

DOI: $10.29141 / 2218-5003-2019-10-2-4$

\section{Моделирование конкурентного поля предприятия: структурный подход \\ Н.Ю. Ярошевич}

Аннотация. Статья посвящена моделированию и эмпирической оценке функционирования конкурентного поля предприятия. Методологическая база исследования основана на включает: теории отраслевых рынков, теории организационных полей и теории конкурентного поля. Доказано, что отраслевой рынок можно рассматривать как конкурентное поле, определенное фирмой (или навязанное ей), где реализуется стратегическое взаимодействие в рамках формируемых статусных иерархий фирм-участников. Такой подход позволяет более полно учесть и сложившуюся на рынке структуру, и поведение фирмы. Для характеристики конкурентного поля предложено использовать показатели структуры рынка, монопольной власти и властной асимметрии. Автором обоснован выбор показателей для их оценки. Для оценки структуры рынка выбран модифицированный индекс Херфиндаля-Хиршмана; для монопольной власти - индекс Бейна; для властной асимметрии - его отклонение. На основании сочетания значений выбранных показателей выделены четыре типа конкурентного поля и построена матрица определения конкурентных полей. Эмпирическая апробация предложенного подхода проводилась на примере 8 отраслей промышленности. Результаты эмпирической части исследования позволили выявить только три типа (из четырех) конкурентного поля в исследуемых отраслях промышленности. Динамический анализ отраслей показал, что все они являются устойчивыми олигополиями с низким уровнем развития конкуренции. Сформировавшиеся на отраслевых рынках конкурентные поля являются своеобразной «ловушкой», так как не стимулируют промышленные предприятия к развитию технологических и управленческих инноваций. Предложенный автором подход является универсальным и может быть использован для определения конкурентного поля на других отраслевых рынках.

Ключевые слова: структура рынка; моделирование; конкурентное поле; предприятие; отраслевой рынок.

JEL Classification: A14, L13, L40, L10

Аата поступления статьи: 20 февраля 2019 г.

Ссылка для цитирования: Ярошевич Н.Ю. Моделирование конкурентного поля предприятия: структурный подход // Управленец. 2019. Т. 10. № 2. С. 31-40. DOI: 10.29141/2218-5003-2019-10-2-4.

\section{Источники}

Бурдье П. (2005). Поле экономики // Бурдье П. Социальное пространство: поля и практики / под ред. Н.А. Шматко. М.: Алетейя. С. 129-176.

Каменский П.В. (1909). Значение торгово-промышленных трестов на Западе и у нас. М.

Карпов А.Л. (2008). Модель конкурентного поведения и конкурентное пространство фирмы // Экономика региона. Приложение к № 4. С. 248-255.

Портер М. (2005). Конкурентная стратегия. Методика отраслей и конкурентов. М.: Альпина Бизнес Букс. С.111-113.

Радаев В. (2010). Как организуется рыночное взаимодействие: препринт WP4/2010/01. М.: ГУ-ВШЭ.

Райзберг Б.А. (2000). Курс экономики. М.: ИНФРА-М.

Рубин Ю.Б. Стратегии конкурентных действий // Современная конкуренция. 2014. № 4 (46). С. 101-143.

Тироль Ж. (2000). Рынки и рыночная власть: теория организации промышленности: в 2 т. / пер. с англ., под ред. В.М. Гальперина и И.А. Зенкевича. СПб.: Экономическая школа. Т 1.

Флигстин Н. (2002). Поля, власть и социальные навыки: критический анализ новых институциональных течений // Экономическая социология: новые подходы к институциональному и сетевому анализу / сост. и науч. ред. В.В. Радаева. М.: РОССПЭН. С.119-156.

Abell D.E. (1980). Defining the Business: The Starting Point of Strategies Planning. Prentice-Hall, Englewood Cliffs.

Adikesavan T.A. (2014). Management information systems: best practices and applications in business. PHI Learning Private Limited. 
Gavetti G. (2012). Toward a Behavioral Theory of Strategy. Organization Science, vol. 23, no. 1 (January-February), pp. $267-285$. Hughes A. (1999). Constructing Competitive Spaces: On the Corporate Practice of British Retailer-Supplier Relationships. Environment and Planning A: Economy and Space, vol. 31, no. 5 (May), pp. 819-839.

Liu Y., Li T. (2005). The Research of Enterprise Competition Behavior and the Theory of Dynamic Competition Environment. Journal of Information, no. 7, pp. 64-66.

Mason E.S. (1939). Price and Production Policies of Large Scale Enterprise. The American Economic Review, no. 29, pp. 61-74.

Scherer F.M., Ross D. (1990). Industrial market structure and economic performance. 3rd ed. Boston: Houghton Miffin Co.

Zhang J.B., Gao D. (2014). Review on the Research of Dynamic Competition Theory. Journal of Human Resource and Sustainability Studies, no. 2, pp. 246-251.

\section{Информация об авторе}

\section{ЯРОШЕВИЧ Наталья Юрьевна}

КандиАат экономических наук, Аоцент кафеАры экономики преАприятий. Уральский государственный экономический университет (620144, РФ, г. Екатеринбург, ул. 8 Марта/Народной Воли, 62/45). E-mail: iarnat@mail.ru. 